\title{
Red-masked Parakeet Aratinga erythrogenys and Grey-cheeked Parakeet Brotogeris pyrrhopterus: two threatened parrots from Tumbesian Ecuador and Peru?
}

\author{
BRINLEY J. BEST, NIELS KRABBE, CHRISTOPHER T. CLARKE and \\ AMANDA L. BEST
}

\section{Summary}

In order to determine whether Aratinga erythrogenys and Brotogeris pyrrhopterus can be formally classified as globally threatened species, their distribution, population sizes and ecological requirements are reviewed, together with national and international trade data from the last decade. The study concludes that, on current data, it is not possible to classify the two species formally, but there are strong indications that, at least locally, the populations of the two species are in decline. The causal factors appear to be a combination of high trade levels and habitat loss. It is essential that trade moratoria are implemented, pending the outcome of further research into the species' population sizes, ecology and breeding success, and further work to determine the extent of trade. Interim recommendations are given and it is proposed that future exploitation of the species should continue only when it has been determined that it has a sustainable basis.

\section{Introduction}

One of the most species-rich Endemic Bird Areas (EBAs) in the Neotropics is situated on the Andean Pacific slope and coastal lowlands of Ecuador and north-western Peru: the Tumbesian Western Ecuador and Peru EBA (Stattersfield et al. in prep.). The region has also been called the Tumbesan or Tumbesian Centre of Endemism by Cracraft (1985) and subsequent authors (e.g. Ridgely and Tudor 1989).

Among the 54 bird species restricted to this area are no fewer than four endemic parrots: Red-masked Parakeet Aratinga erythrogenys, El Oro Parakeet Pyrrhura orcesi (discovered as recently as 1980), Pacific Parrotlet Forpus coelestis and Grey-cheeked Parakeet Brotogeris pyrrhopterus. Pyrrhura orcesi is known to be globally threatened due to its tiny range in Ecuador's El Oro and Azuay provinces and because of its reliance on humid forest; it is listed as Vulnerable/ Rare in Collar et al. (1992) and Vulnerable in Collar et al. (1994). Forpus coelestis, on the other hand, is clearly not at risk, since it is common throughout the region in degraded scrub and agricultural land, and appears to be in little demand locally or internationally as a cage bird. The status of Aratinga erythrogenys and Brotogeris pyrrhopterus is, however, less clear. In $1988 \mathrm{~B}$. 
pyrrhopterus was thought to be threatened, but $A$. erythrogenys not (Collar and Andrew 1988). Both species were then extensively researched by N.K. for inclusion as globally threatened in Collar et al. (1992), but were finally appended in that work as "near-threatened". This status was also given to them in Collar et al. (1994), after re-evaluation using the new IUCN criteria (see Mace and Stuart 1994). Ornithologists still disagree on the status of the two species, some preferring to consider them globally threatened, based on concern that there is evidently some decline occurring in the wild, caused by a combination of habitat destruction and trapping for the bird trade.

In view of these uncertainties the aims of this paper are twofold: first, to present the detailed distributional and ecological data collected on the two species for the Red Data Book project which otherwise might be "lost"; second, using this information together with CITES trade figures and other relevant data, to assess whether it is possible to classify the two species formally as threatened, given the present state of knowledge.

\section{International trade controls and national legislation relating to Tumbesian parrots}

Ecuador and Peru are both parties to the Convention on Trade in Endangered Species of Wild Fauna and Flora (CITES). Aratinga erythrogenys and Brotogeris pyrrhopterus are listed in Appendix II of CITES, and therefore should be permitted for export by a country only after it has been established that such trade is not detrimental to their survival. In the 1970 s both Ecuador and Peru temporarily banned the export of wildlife and, as Peru had previously been an important parrot exporter, other countries (e.g. Argentina) witnessed a boom in their parrot exports after these bans. However, in the late 1970s Peru permitted export in its wildlife once again but on a selective basis: only trade in species from the sierra and coastal regions was permitted (Fuller et al. 1987). In 1983 the Peruvian government established a quota system regulating exports (Fuller et al. 1987). During the same year, Ecuador banned export of all indigenous wildlife, except for educational, cultural or scientific reasons. Peru also has a decree dating from 1973 that prohibits the hunting and trading of birds from the Amazonian lowlands, but there appears to be no equivalent law in place in Ecuador concerning domestic trade in parrots.

Trade in these species is also restricted by controls in key consumer markets. A. erythrogenys and B. pyrrhopterus were banned from import into the European Union from Peru in 1986 and 1991 respectively. Perhaps more significantly, in October 1993 the U.S.A., previously the main consumer of these and other Neotropical parrot species, banned the import of virtually all CITES-listed bird species, including $B$. pyrrhopterus and $A$. erythrogenys. This ban may be lifted selectively on a species-by-species, country-by-country basis, pending approval by the U.S. Scientific and Management Authorities of management plans and trade controls in the countries of export. More detailed information on international trade in each species is given in the species accounts which follow.

As far back as 1984 concerns that CITES Appendix II species were being traded without the benefit of "non-detriment" findings prompted the CITES Technical Committee to initiate a review of all Appendix II species traded 
between 1980 and $\mathbf{1 9 8 2}$. This concluded that several species were being traded at levels detrimental to their survival, and the population status of a larger number, including $A$. erythrogenys and $B$. pyrrhopterus, was insufficiently known to make determinations of trade impacts. A more recent review of trade data for selected species, covering the period 1983-1988, has been carried out on behalf of the CITES Animals Committee by the World Conservation Monitoring Centre and the IUCN Trade Specialist Group (Inskipp and Corrigan 1992). Both $A$. erythrogenys and $B$. pyrrhopterus were included in this review and the findings are given in each species account.

\section{Red-masked Parakeet Aratinga erythrogenys}

\section{Distribution}

This species is distributed from Manabí province, north-western Ecuador, at $0^{\circ} 05^{\prime} \mathrm{S}$, south to Lambayeque department in north-western Peru at $5^{\circ} 59^{\prime} \mathrm{S}$ (Figure 1). In addition to Manabí and Lambayeque, it occurs in the Ecuadorian provinces of Pichincha, Manabí, Los Ríos, Guayas, Azuay, El Oro and Loja, and the Peruvian departments of Tumbes, Piura and Cajamarca. It is found from sea-level to $2,500 \mathrm{~m}$, but is most frequently recorded below 1,500 $\mathrm{m}$. The high Andes constitute an easterly limit to its distribution in Ecuador. The bird occurs in eight protected areas, seven of which are in Ecuador: Cerros Mutiles Reserve, Río Palenque Reserve, Jauneche Reserve, Machalilla National Park, Cerro Blanco Reserve, Manglares-Churute Ecological Reserve and Arenillas Military Reserve, and one in Peru: the North-West Peru Biosphere Reserve (occurring in two of the three areas which comprise this reserve: the Tumbes National Forest and El Angolo Hunting Reserve). There is a zone in the centre of the range of $A$. erythrogenys in Guayas, El Oro and Azuay provinces, where there are very few records (Figure I). This, if real, effectively divides the population into two rather distinct subpopulations between which there may be little genetic mixing.

\section{Population}

In the early 1920s, the species was reported by Chapman (1926) to be locally common in both north-western Peru and south-western Ecuador. Ridgely (1981), writing some 55 years later, was of a similar opinion, whereas O'Neill (1981) stated that the parrot was abundant in Peru. Best and Clarke (1991) and Best et al. (1992) reported the species to be "common" in extreme southern Loja province, and L. Kiff (in litt. 1992) and Williams and Tobias (1994) described the species as "very common" and "common" in the Sabanilla and Hacienda Linderos areas of Loja province in early 1991. Nevertheless, severe local declines have been recorded. In the late 1970s, thousands were regularly seen flying over Guayaquil, but by 1980 only 125 were recorded in the same season (Ridgely 1981). P. Greenfield (in litt. 1989) stated that flocks in this area now rarely exceed a few tens of birds. Most observations today refer to flocks of less than 50 individuals. A similar decline has occurred in the lowlands of El Oro province, and on the Santa Elena Peninsula in Guayas province (R. S. Ridgely in litt. 


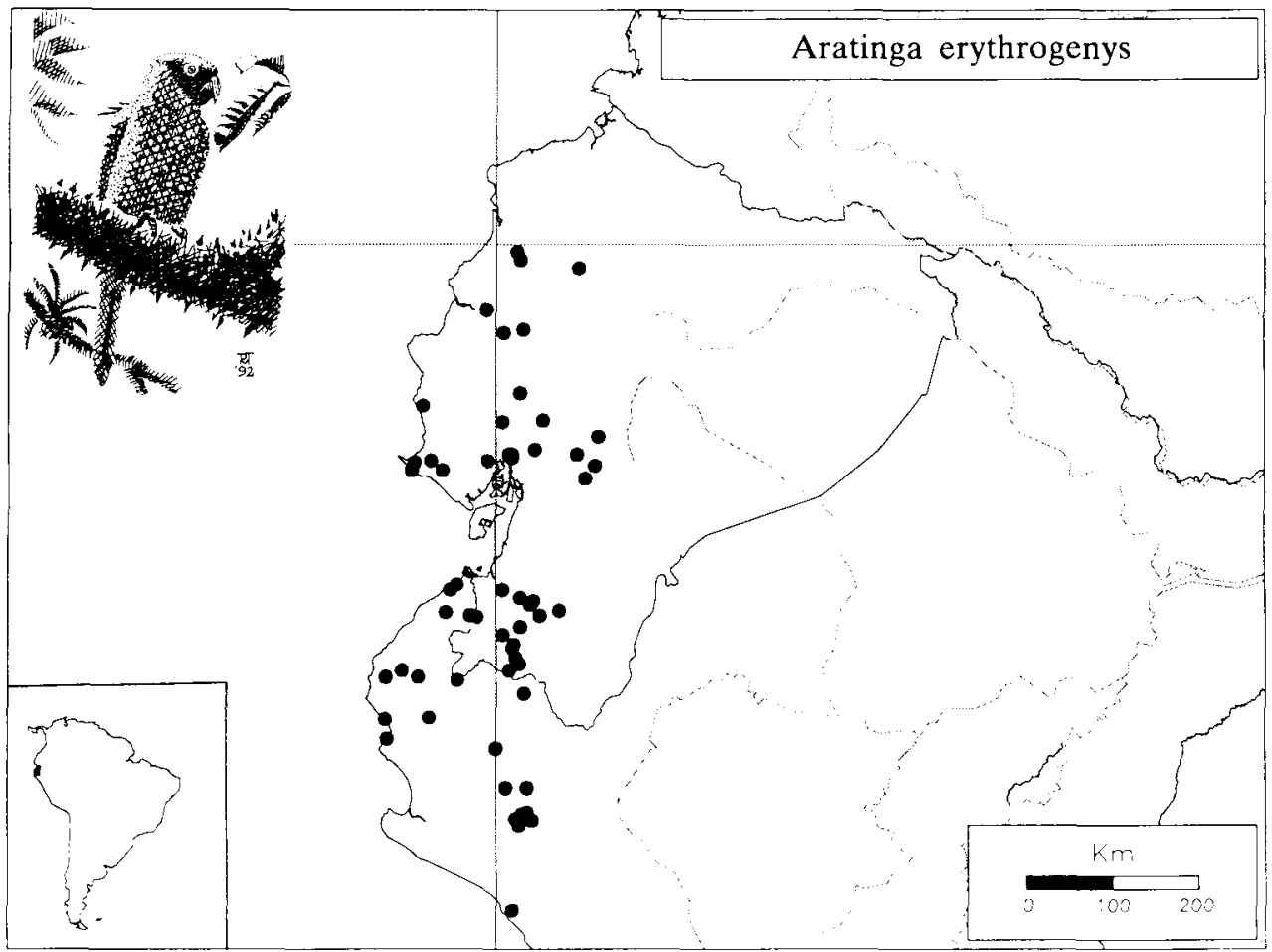

Figure 1. Distribution of Aratinga erythrogenys.

1995). Recent observations of larger flocks are detailed in Table 1. Any estimates of population size will be, at best, tentative. However, based on these data and our own observations in the Tumbesian region we believe the total population is

Table 1. Recent noteworthy sightings of Red-masked Parakeet Aratinga erythrogenys in Ecuador and Peru. Only those records involving 50 birds or more are listed.

\begin{tabular}{lccll}
\hline $\begin{array}{l}\text { Locality and } \\
\text { Province/Department }\end{array}$ & Number & Year & Month & Source \\
\hline ECUADOR & & & \\
Guayaquil, Guayas & Thousands & $1976-1973$ & July-September & Ridgely (1981) \\
Guayaquil, Guayas & 125 & 1980 & July-September & Ridgely (1981) \\
Arenillas, El Oro & $100+$ & 1980 & August & R. S. Ridgely (in litt. 1995) \\
West of Piñas, El Oro & $50-75$ & 1985 & June-July & R. S. Ridgely (in litt. 1995) \\
Near Zaruma, El Oro & 150 & 1990 & June & P. Coopmans (in litt. 1991) \\
Vicentino, Loja & 60 & 1991 & February & Best et al. (1992) \\
Tierra Colorada, Loja & 82 & 1991 & February & Best et al. (1992) \\
Celica, Loja & 70 & 1991 & February & Best et al. (1992) \\
Hacienda Linderos, Loja & 145 & 1991 & August & Williams and Tobias (1994) \\
Sozoranga, Loja & 200 & 1989 & June & Bloch et al. (1991) \\
Tambo Negro, Loja & 140 & 1989 & August & Best and Clarke (1991) \\
Amaluza, Loja & 80 & 1990 & August & Williams and Tobias (1994) \\
PERU (all Piura) & & & & \\
El Tocto & $70+$ & 1987 & May & M. Pearman (in litt. 1991) \\
Mano de León/El Tocto & $120+$ & 1987 & May & M. Pearman (in litt. 1991) \\
Quebrada Caballito & $150+$ & 1987 & June & M. Pearman (in litt. 1991) \\
\hline
\end{tabular}


unlikely to be smaller than 10,000 birds, with the majority occurring in Ecuador.

Assessments of population changes are difficult to make. Marchant's (1958) observations illustrate that natural interannual variability, let alone seasonal variability, is very significant, for he classified A. erythrogenys as a "scarce to numerous" non-breeding visitor to the Santa Elena Peninsula in coastal Guayas province, Ecuador. Besides having to account for such short-term changes, there is the problem of separating localized and more wide-ranging effects. It is not known, for example, whether the Guayaquil decline is indicative of a general population reduction, or merely reflects local changes (Ridgely 1981). P. Greenfield (in litt. 1989) recorded that "its numbers have fallen drastically due to habitat destruction as well as due to pet trade in Ecuador and abroad".

\section{Ecology}

A variety of habitats are favoured, from humid forest through deciduous forest and dry, Acacia scrub to open, sparsely vegetated desert (Ridgely 1981, Best et al. 1992). Records are also known from around towns and cities as well as intensively farmed habitats (Ridgely 1981, Best et al. 1992, Williams and Tobias 1994). Although principally a bird of arid areas, there are some Ecuadorian records from humid locations, such as near Muisne in Esmeraldas province (R. S. Ridgely in litt. 1995), at Jatumpampa and Tierra Colorada in Loja province (Best and Clarke 1991, Best et al. 1992), and Río Palenque, Los Ríos province (P. Coopmans in litt. 1991).

Very little has been recorded on the feeding preferences of the species but food plants are likely to be highly variable, depending on local and seasonal sources. In south-western Ecuador it fed on Erythrina flowers when fruit was scarce (Best and Clarke 1991). When fruit is available it is readily taken: birds have been seen feeding on the fruit of Anacardiaceae, Olaraceae and Boraginaceae trees (Silva 1993), and a flock of 40 were attracted to the fruit of a Hyeronima tree (Williams and Tobias 1994).

Aratinga erythrogenys is a highly gregarious bird, particularly during the dry (non-breeding) season, when it gathers in large flocks. In the breeding season it occurs more commonly in pairs. Best and Clarke (1991) regularly recorded flocks of up to 140 individuals flying to communal roosts at dusk in August 1989. The following morning larger but less numerous flocks were seen flying in the opposite direction, presumably in search of feeding sites. The species has been found in mixed-species flocks with $B$. pyrrhopterus and Bronze-winged Parrot Pionus chalcopterus in south-west Ecuador (Best et al. 1992).

Marchant (1958) and K. Berg (in litt. 1993) provide evidence that $A$. erythrogenys undertakes local seasonal movements. Marchant (1958) found that on the Santa Elena Peninsula the birds usually arrived after the onset of the annual rains from April onwards, probably having bred elsewhere, whereas $\mathrm{K}$. Berg (in litt. 1993) reported that at Manta Real in Azuay province the species was apparently absent during the wet season (January-March).

\section{Breeding}

Breeding occurs in nests excavated from termite mounds (Platt 1991) or in holes in trees such as Ceiba trichistandra and Cochlospermum vitifolium (Chávez-Riva 
1991, Best et al. 1992). The only detailed data on breeding come from ChávezRiva's study in the El Angolo Hunting Reserve (part of the North-West Peru Biosphere Reserve) in Tumbes department. Here the breeding season starts between March and April and lasts until July. The species nests in dry forest between 400 and $800 \mathrm{~m}$ above sea level, with nests situated $2.5-10 \mathrm{~m}$ above the ground, often where fallen branches leave natural cavities. Breeding success is variable, with 2-4 eggs being laid and between 1 and 4 of these actually hatching (an unknown number fledge). Young apparently spend some time with their parents after hatching. Interannual variations in breeding activity have been recorded at El Angolo, probably caused by the natural variability of the rainy season. In captivity the young have been recorded as fledging after six weeks, following 23 days of incubation (Arndt 1986).

The breeding season varies from one place to another. Silva (1993) stated that in Ecuador it extends from January to March, with the young fledging in April. Similarly, in the surveys of Best et al. (1992) in Azuay, El Oro and Loja provinces, evidence of breeding activity, notably nest-hole investigation, allopreening and copulation, was recorded between January and March.

\section{Threats}

Habitat loss It is difficult to assess the risk from habitat loss since so little is known about the species's dependence on forest. Furthermore, although it is known that $A$. erythrogenys nests in tree cavities, it is unclear to what extent it tolerates logged forest and whether it breeds successfully in small woodlots, or even single isolated trees. Detailed ecological studies are needed.

Although it is often recorded in forested localities, many observers have recorded $A$. erythrogenys in agricultural land or in areas of scrub (M. Pearman in litt. 1991, Best et al. 1992, Williams and Tobias 1994). However, as it is most frequently recorded in forest, the widespread destruction of this habitat within its range is a cause for concern. Dodson and Gentry (1991) showed that a catastrophic loss of forest has occurred within the Tumbesian region in the last 50 years, and the documented declines in the species's numbers raise the possibility that habitat destruction, as well as collecting for the bird trade, are affecting it.

Local trade Aratinga erythrogenys is the most commonly kept parrot in captivity in south-west Ecuador (Best and Clarke 1991, Williams and Tobias 1994). Indeed, it is highly regarded as a pet species throughout Ecuador and Peru, and therefore enjoys the questionable privilege of being the most heavily traded Aratinga species within these countries (Silva 1993). It can apparently learn to talk (K. Berg in litt. 1993, Silva 1993). There are few published data on the extent and methodology of local collecting. In Ecuador it is known to be captured near Chacanseo in Azuay province to be sold in the nearby settlements of La Troncal and Cuenca (K. Berg in litt. 1993), and captive birds in the town of Alamor were said to have been obtained from the border town of Huaquillas (Best et al. 1992). It is likely that the peak capture period is during the breeding season, in the $\mathrm{mid} / \mathrm{late}$ hatching stage, as has been recorded in south-west Ecuador for $B$. 
Table 2. Minimum net imports of live Aratinga erythrogenys reported to CITES, 1983-1988. Only those countries receiving at least 100 birds in any one year are listed separately.

\begin{tabular}{lrrrrrrr}
\hline Country & 1983 & 1984 & 1985 & 1986 & 1987 & 1988 & Total \\
\hline Austria & 0 & 0 & 30 & 0 & 0 & 100 & 130 \\
Belgium & 0 & 70 & 590 & 2 & 0 & 0 & 662 \\
Canada & 400 & 75 & 645 & 90 & 0 & 0 & 1,210 \\
Denmark & 20 & 50 & 100 & 0 & 0 & 20 & 190 \\
Germany (Fed. Rep.) & 151 & 101 & 640 & 180 & 68 & 330 & 1,470 \\
Italy & 0 & 0 & 100 & 2 & 1 & 0 & 103 \\
Netherlands & 20 & 130 & 55 & 50 & 0 & 45 & 300 \\
Spain & 610 & 185 & 809 & 203 & 0 & 561 & 2,368 \\
Sweden & 0 & 200 & 0 & 201 & 0 & 0 & 401 \\
U.K. & 0 & 290 & 100 & 40 & 1 & 2 & 433 \\
U.S.A. & 3,456 & 13,402 & 12,934 & 7,874 & 2,688 & 4,175 & 44,529 \\
Others & 0 & 16 & 16 & 1 & 12 & 12 & 58 \\
Total & 4,657 & 14,519 & 16,019 & 8,643 & 2,770 & 5,245 & 51,853 \\
\hline Source & & & & & & &
\end{tabular}

Source: Inskipp and Corrigan (1992).

pyrrhopterus (Platt 1991) and for many parrot species in Venezuela (Desenne and Strahl 1991).

International trade Several recent studies (e.g. Thomsen and Bräutigam 1991, Collar and Juniper 1992, Thomsen and Mulliken 1992) have emphasized the role of the bird trade as a major threat to many Neotropical parrots, an idea endorsed by Silva (1993) and others as the major cause of the decline in $A$. erythrogenys. The species is commonly exported for the international cagebird trade: from 1981 to 1985 it was the tenth commonest Neotropical psittacine species imported into the U.S.A., with 26,375 birds recorded (Thomsen and Bräutigam 1991). Between 1982 and 1986 it constituted $35 \%$ of Peru's parrot exports. Import and export data for A. erythrogenys for 1983-1988 are given in Tables 2 and 3 .

From 1980 to 1982 the mean annual net trade reported to CITES was only 199 birds. Remarkably, this increased to an average figure of 8,642 birds annually between 1982 and 1988. CITES annual report data show that exports remained just under 8,000 birds in 1989 and 1990, but surpassed 9,000 in 1991 (T. A. Mulliken in litt. 1995). As a result of Ecuador's export ban Peru stands out as by far the most significant exporter of the species during the period to 1988 , with reported exports peaking in 1985 . The U.S.A. is clearly the most notable

Table 3. Reported countries of origin (or exporting country if no original source is reported) and quantities of transactions of live Aratinga erythrogenys reported to CITES, 1983-1988.

\begin{tabular}{lrrrrrrr}
\hline Country & 1983 & 1984 & 1985 & 1986 & 1987 & 1988 & Total \\
\hline Ecuador & 2 & 2 & 0 & 0 & 0 & 0 & 4 \\
Peru & 4,405 & 14,516 & 15,835 & 8,417 & 2,768 & 5,243 & 51,184 \\
Other countries $^{a}$ & 250 & 1 & 184 & 226 & 2 & 2 & 665 \\
Total & 4,657 & 14,519 & 16,019 & 8,643 & 2,770 & 5,245 & 51,853 \\
\hline
\end{tabular}

a Without wild populations of the species.

Source: Inskipp and Corigan (1992). 
Table 4. Market value in USS of selected Neotropical parrots between 1987 and 1992.

\begin{tabular}{llcc}
\hline Species & Peru & Ecuador & U.S.A. \\
\hline Brotogeris pyrrhopterus & $10-12$ & $1-2$ & $99-385$ \\
B. versicolurus & - & - & $75-100$ \\
B. sanctithomae & - & - & $60-385$ \\
Touit huetii & - & - & $60-385$ \\
T. purpurata & - & - & $60-385$ \\
Aratinga erythrogenys & - & - & $43-399$ \\
A. leucophthalmus & - & - & $59-270$ \\
A. weddelli & - & $125-140$ \\
\hline
\end{tabular}

Sources: Platt (1991), T. S. Schulenberg (in litt. 1991), T. Mulliken verbally (1993), B. J. Weissgold in litt. to TRAFFIC International (1993).

importer of the species, yet a 1990 survey revealed that it is not commonly bred in captivity in that country, with just 31 young raised from 64 breeding pairs in 1989 (Allen and Johnson 1991). The high numbers of A. erythrogenys apparently in trade seem at first sight surprisingly high; it seems likely that the species is smuggled over the border from Ecuador and the birds exported as Peruvian. Inskipp and Corrigan (1992) put forward an alternative hypothesis that exported parrots declared as $A$. erythrogenys were in fact Amazonian species, which are officially banned from export from Peru. This would provide a means for these species, also forbidden from export from many other countries, to enter international trade.

It is difficult to assess the threat from trade as so little is known about the population size of the species and recruitment in the wild. Mis-declaring may tend to inflate the number appearing in international trade. However, pre-export mortality can be high, as shown by Ramos and Iñigo's (1985) study from Mexico, where losses amounted to $60 \%$ of the birds trapped for illegal export: conversely, therefore, trade figures may underrepresent the damage being done to populations. This demonstrates the complexities surrounding the estimation of the true numbers of $A$. erythrogenys being taken from the wild.

Inskipp and Corrigan (1992) concluded that current trade levels probably do not threaten the species's global survival. Nevertheless, the CITES Animals Committee recommended that the CITES Management Authority of Peru establish an export quota consistent with sustainable offtake of the species, and inform the Animals Committee of the scientific basis of Peru's management programme accompanying this quota. This course of action has not been adopted by the Peruvian government, and in April 1993 the Standing Committee recommended that CITES Parties suspend the import of this species from Peru until such time as the recommendations were adhered to.

Comparative prices for A. erythrogenys, B. pyrrhopterus and other small parrots, both within Ecuador and Peru, and in the U.S.A., are given in Table 4, which demonstrates that there is an economic incentive to export similar-sized species to $A$. erythrogenys and $B$. pyrrhopterus from Ecuador and Peru. It is also clear that a consicierable mark-up in price occurs for birds sold in the U.S.A.

Other threats The species is known to invade agricultural land in search of food, and human persecution is likely to occur where the species becomes a 
persistent pest, although no data exist on this. Corn crops are thought to be especially at risk from predation.

\section{Grey-cheeked Parakeet Brotogeris pyrrhopterus}

\section{Distribution}

This species occurs from Manabí province, western Ecuador, at $0^{\circ} 4 I^{\prime} S$, to Piura department, north-western Peru, at $4^{\circ} 26^{\prime} \mathrm{S}$ (Figure 2). It is found in the Ecuadorian provinces of Manabí, Los Ríos, Guayas, Azuay, El Oro and Loja, and Peru's Tumbes and Piura departments. The species ranges from sea-level to $300 \mathrm{~m}$ in the provinces of Manabí, Los Ríos, and Guayas (Berg 1994), but in the southern part of its range in Loja it has been recorded up to 1,550 $\mathrm{m}$ (Best et al. 1992). It occurs in four protected areas: Cerro Blanco Reserve, Arenillas Military Reserve and Manglares-Churute Ecological Reserve in Ecuador, and Tumbes National Forest in Peru.

Figure 2 shows that there are two main areas occupied by B. pyrrhopterus: the Ecuadorian coastal provinces of Manabí and Guayas, and the south-western corner of Ecuador and adjacent Tumbes department in north-west Peru. Although it was previously recorded from several sites along the Rio Babahoyo in Guayas province, Ecuador, there are no recent records from that area, despite surveys there. We believe the large-scale conversion of much of that region to agricultural land to be the main cause of the species's disappearance from the Babahoyo area, since only $50 \mathrm{~km}$ to the south-west it thrives in deciduous forest at Cerro Blanco.

\section{Population}

In the early part of this century Brotogeris pyrrhopterus was described as "common" by Chapman (1926), whilst Brosset (1964) described it as "very common" in one location in western Ecuador, especially in the vicinity of banana plantations. R. S. Ridgely's surveys of various sites in western Ecuador from the mid-1970s onwards revealed it to be "never really common" and he never saw anything like as many as those recorded by Brosset (Ridgely 1981). He stated that it is by far the least common of the endemic parrots found in western Ecuador and has suffered a decline in numbers in recent years. This has been confirmed on a more local basis in the El Oro region of Ecuador by Platt (1991), who suggests a combination of trapping, habitat loss and possible scarcity of nest sites may be to blame for the reduction in flock size and frequency noted there.

Recent noteworthy sightings involving flocks of over 50 birds are listed in Table 5. Additionally Best et al. (1992) found small groups totalling up to 40 birds in a variety of locations in the early 1990s in south-western Ecuador, the species being recorded as "common" at Tambo Negro in extreme southern Loja province. However, in some apparently suitable areas birds seem inexplicably scarce, perhaps owing to seasonal movements. P. Coopmans (in litt. 1991) found B. pyrrhopterus in a variety of locations in the early 1990s, but only in small numbers. Between Celica and El Empalme he considered the bird to be "surpris- 


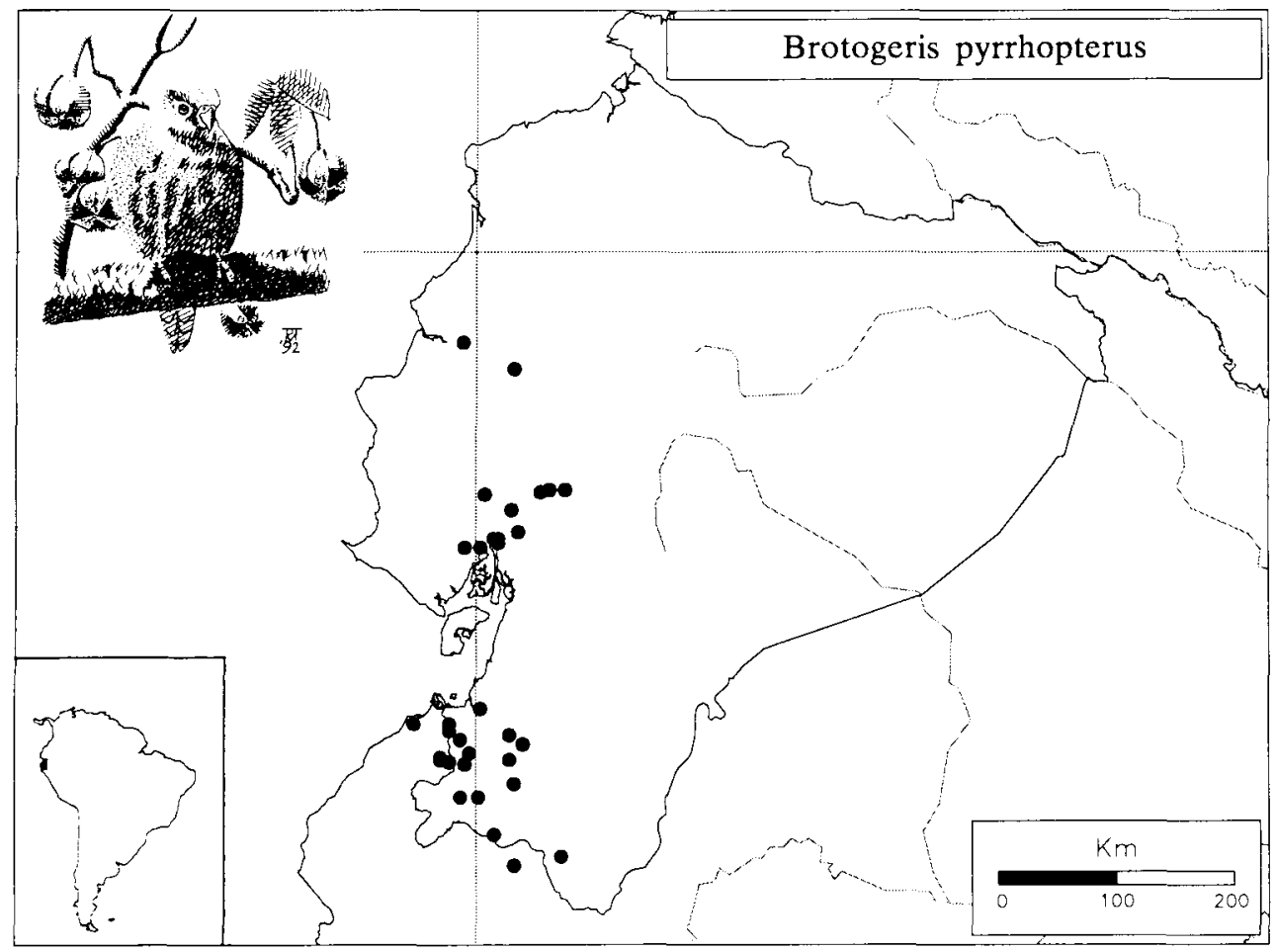

Figure 2. Distribution of Brotogeris pyrrhopterus.

ingly uncommon", yet M. B. Robbins (in litt. 1991) found up to 30 daily nearby in 1989. Williams and Tobias (1994) noted that the species was "remarkably scarce" during their 1990-1991 surveys of the Amaluza region in Loja province, despite the presence of much suitable habitat.

In Peru, B. pyrrhopterus appears to be even scarcer than in Ecuador, except for a few locations such as at El Caucho, Tumbes, where it is still "fairly common"

Table 5. Recent noteworthy sightings of Grey-cheeked Parakeet Brotogeris pyrrhopterus in Ecuador and Peru. Only those records involving 50 birds or more are listed.

\begin{tabular}{|c|c|c|c|c|}
\hline $\begin{array}{l}\text { Locality and } \\
\text { Province/Department }\end{array}$ & Number & Year & Month & Source \\
\hline \multicolumn{5}{|l|}{ ECUADOR } \\
\hline Cerro Blanco, Guayas & 50 & $1992-1993$ & All months & $\begin{array}{l}\text { P. Donahue (in litt. 1991), } \\
\text { Berg (1994) }\end{array}$ \\
\hline $\begin{array}{l}\text { Between Arenillas and } \\
\text { Puerto Pitthaya, Loja }\end{array}$ & $50+$ & 1991 & January & C. Balchin (in litt. 1991) \\
\hline Tambo Negro, Loja & 60 & 1989 & August & Best and Clarke (1991) \\
\hline \multicolumn{5}{|l|}{ PERU } \\
\hline Tumbes town, Tumbes & $\begin{array}{l}5 \text { flocks } \\
\text { totalling } \\
80 \text { birds }\end{array}$ & 1979 & February & Krabbe (1984) \\
\hline El Caucho, Tumbes & $60-120$ & 1986,1988 & $\begin{array}{l}\text { February-March, } \\
\text { June }\end{array}$ & Parker et al. (1995) \\
\hline
\end{tabular}


(Wiedenfeld et al. 1985). Subsequent surveys there estimated daily counts of between 60 and 120 individuals (Parker et al. 1995, this issue). It was here that a sizeable population of a few hundred was found in February 1986 (M. Kessler in litt. 1988). The Tumbes National Forest and the two contiguous reserves of Cerros de Amotape and El Angolo constitute the most important Peruvian site for the species. Five flocks totalling 80 individuals were seen near the town of Tumbes in 1979 (N.K. pers. obs.), but elsewhere in Peru T. A. Parker described it as both rare and local (Ridgely 1981). Based on all the above data and on field experience in the Tumbesian region we believe the total population of $B$. pyrrhopterus is unlikely to exceed 15,000 birds, the majority of these occurring within Ecuador.

\section{Ecology}

The species is reported from a wide range of habitat types: Best et al. (1992) found the species in disturbed humid forest below Vicentino in Loja province, Ecuador, and Parker et al. (1995, this issue) encountered B. pyrrhopterus in evergreen forest at Campo Verde in Tumbes department, Peru. It is also known from deciduous Ceiba trichistandra forest and scrub (Williams and Tobias 1994), and arid Acacia-dominated scrubland and semi-open agricultural land, but it appears to be most numerous in deciduous forest.

A few food sources have been recorded, including the petals and seeds of Erythrina trees (Best and Clarke 1991), flowers and seeds of a Chorisa sp., flowers of Cavanillesia platanifolia (Parker et al. 1995, this issue), Ceiba and Ficus fruit (Best et al. 1992), and catkins of a Cecropia sp. (Parker et al. 1995, this issue; also R. S. Ridgely in litt. 1989).

The birds are usually encountered in pairs or small flocks of 4-10, sometimes with other species, including $A$. erythrogenys and Pionus chalcopterus (Best et al. 1992). Larger flocks have been recorded (Table 5), though no recent observations approach the numbers described by Brosset (1964). Ridgely (1981) stated that, unlike its congeners, it does not usually occur in large flocks. Parker et al. (1995) add that it is likely to undertake local seasonal movements.

\section{Breeding}

Like A. erythrogenys, B. pyrrhopterus favours nesting cavities in trees (K. Berg in litt. 1993) and some individuals have been recorded laying eggs on decaying wood or moist moss in hollow tree limbs or trunks (Harris 1985). Termite mounds are also favoured and where these are found the birds tunnel to excavate sufficient space. The termites continue to use their nest, patching up the damage caused by the parakeets (Harris 1985).

Evidence of breeding has been recorded from February to August. It is not known whether this is due to large interannual variations or whether the breeding season is itself very long. Best et al. (1992) found frequent examples of breeding behaviour, including copulation, allopreening and birds investigating potential nest cavities in Ceiba trees, at Tambo Negro in February 1991. In the same location copulation was also observed during the latter part of August 1989 (Best and Clarke 1991). Two out of seven specimens collected in July and 
deposited at the American Museum of Natural History had slightly enlarged gonads (N. J. Collar verbally 1990). The main breeding season is likely to coincide with the wet season (January-March), as is the case for most bird species in this region of highly seasonal rainfall (Marchant 1958, Best et al. 1992).

Captive breeding records show that $4-7$, but usually 5 , eggs are laid, and the young fledge after six weeks and are fed for a further three (Arndt 1986).

\section{Threats}

Habitat loss Many of the comments made for A. erythrogenys are also relevant to this species, and similarly it is difficult to judge the threat that habitat disturbance poses. Ridgely (1981) noted that $B$. pyrrhopterus ranges out into semi-open agricultural land where large trees are left standing, and M. Kessler (in litt. 1990) stated that it requires large trees such as Erythrina or Bombax for nesting. Ridgely (1981) considered that "it is quite possible that the conversion of so much of the original woodland and scrub has caused a decline". He supported this assertion by the observation that the species is somewhat more numerous in what remains of native habitats. Only further research can properly reveal the threat habitat destruction poses to B. pyrrhopterus.

Local trade The species is commonly kept as a cage-bird in the Tumbesian region, but not as frequently as $A$. erythrogenys (Williams and Tobias 1994). The only data on local trade come from Platt (1991) who documents its capture in El Oro province, Ecuador. The whole brood is taken at a young age from nests hollowed out of termite nests and sold either locally or in nearby towns for US\$2 per bird or less. The collecting period lasts from January to March as this is the breeding season. Many birds are apparently sold to military and police personnel nearing the end of their tours of duty; birds are also sold to tourists at the Puyango Petrified Forest. Families engaged in trade in B. pyrrhopterus apparently do not obtain great financial reward from bird trapping, but it supplements the income they receive from arable and livestock farming. Birds are sometimes taken in crates to larger centres (e.g. Machala) where they are sold on to dealers. At Macará in southern Loja province in 1989 the species was found commonly in captivity, with one owner stating that the birds are often caught when they visit the fields to feed on ripe crops; they were said to cost US\$1.50 each in that year (Best and Clarke 1991).

In Peru a great many people keep the species as pets (Harris 1985). Birds have been found for sale in a Lima market for US\$10-12 each (Plowden 1987); at this market non-Peruvian parrot species were available, suggesting that importation of birds into Peru is not unknown (Thomsen and Bräutigam 1991). It is possible that B. pyrrhopterus sold in Peru may have been smuggled into the country from Ecuador for sale on domestic markets.

International trade Brotogeris pyrrhopterus is commonly exported for the international cage-bird trade; from 1981 to 1985 it was the fifth commonest Neotropical psittacine species imported into the U.S.A., with 50,186 birds recorded (Thomsen and Bräutigam 1991). It constituted 34\% of Peru's parrot trade between 1983 and 1988 , and together with $A$. erythrogenys the two species total 
Table 6. Minimum net imports of live Brotogeris pyrrhopterus reported to CITES, 1983-1988. Only those countries receiving at least 100 birds in any one year are listed separately.

\begin{tabular}{lrrrrrrr}
\hline Country & 1983 & 1984 & 1985 & 1986 & 1987 & 1988 & Total \\
\hline Austria & 0 & 0 & 0 & 0 & 0 & 100 & 100 \\
Belgium & 210 & 700 & 375 & 0 & 0 & 0 & 1,285 \\
Germany (Fed. Rep.) & 37 & 220 & 510 & 0 & 0 & 0 & 767 \\
Japan & 414 & 30 & 0 & 0 & 0 & 0 & 444 \\
Sweden & 0 & 0 & 250 & 0 & 0 & 0 & 250 \\
Switzerland & 0 & 150 & 170 & 0 & 0 & 96 & 416 \\
U.K. & 0 & 100 & 100 & 1 & 0 & 1 & 202 \\
U.S.A. & 729 & 19,151 & 10,200 & 7,894 & 6,868 & 10,786 & 55,628 \\
Others & 37 & 125 & 60 & 4 & 0 & 2 & 228 \\
Total & 1,427 & 20,476 & 11,665 & 7,899 & 6,868 & 10,985 & 59,320 \\
\hline
\end{tabular}

Source: Inskipp and Corrigan (1992).

$69 \%$ of all Peruvian parrots traded between those years (calculated using data from Inskipp and Corrigan 1992 and Thomsen and Bräutigam 1991). In the early 1970 s the species became scarce in captivity after both Ecuador and Peru had imposed export bans, but since Peru's ban was lifted in 1979 the numbers in trade have risen very sharply (Inskipp and Corrigan 1992). Confirmation that birds of this species are removed from the nest at a very young age lies in the fact that some arrive in quarantine in the U.S.A. still unable to eat for themselves (Harris 1985). Tables 6 and 7 give export and import data for the years 19831988.

As with $A$. erythrogenys Peru dominates the export data for B. pyrrhopterus, especially in 1984 when in excess of 20 ,000 were exported in a single year. Similarly, the U.S.A. is the principal consumer. Export of the species from Ecuador was banned in 1983 yet in 1984 there were 125 reported as exported from that country, thereby contravening the ban. CITES annual report data show that international trade levels dropped to approximately 6,500 birds in 1989, then climbed to over 10,000 birds in 1990 and 1991 (T. A. Mulliken in litt. 1995). As with $A$. erythrogenys the numbers of birds in trade seems surprisingly high and we believe these figures must partially represent birds smuggled into Peru via Ecuador where the species is more widespread. Some mis-declaring, as discussed above for $A$. erythrogenys, also seems likely. B. pyrrhopterus is scarce in comparison with its Amazonian relatives $B$. cyanocephala and $B$. versicolorus (Parker et al. 1995). Table 4 shows that other species of similar size to B. pyrrhopterus command a good price, making trade in them productive.

Table 7. Reported countries of origin (or exporting country if no original source is reported) and quantities of transactions of live Brotogeris pyrrhopterus reported to CITES, 1983-1988.

\begin{tabular}{lrrrrrrr}
\hline Country & 1983 & 1984 & 1985 & 1986 & 1987 & 1988 & Total \\
\hline Ecuador & 19 & 125 & 0 & 0 & 0 & 0 & 144 \\
Peru & 1,390 & 20,351 & 11,665 & 7,893 & 6,868 & 10,982 & 59,149 \\
Other countries $^{2}$ & 18 & 0 & 0 & 6 & 0 & 3 & 27 \\
Total & 1,427 & 20,476 & 11,665 & 7,899 & 6,868 & 10,985 & 59,320 \\
\hline
\end{tabular}

"Without wild populations of the species.

Source: Inskipp and Corrigan (1992). 
Table 8. Factors which prevent determination of the conservation status of Aratinga erythrogenys and Brotogeris pyrhopterus.

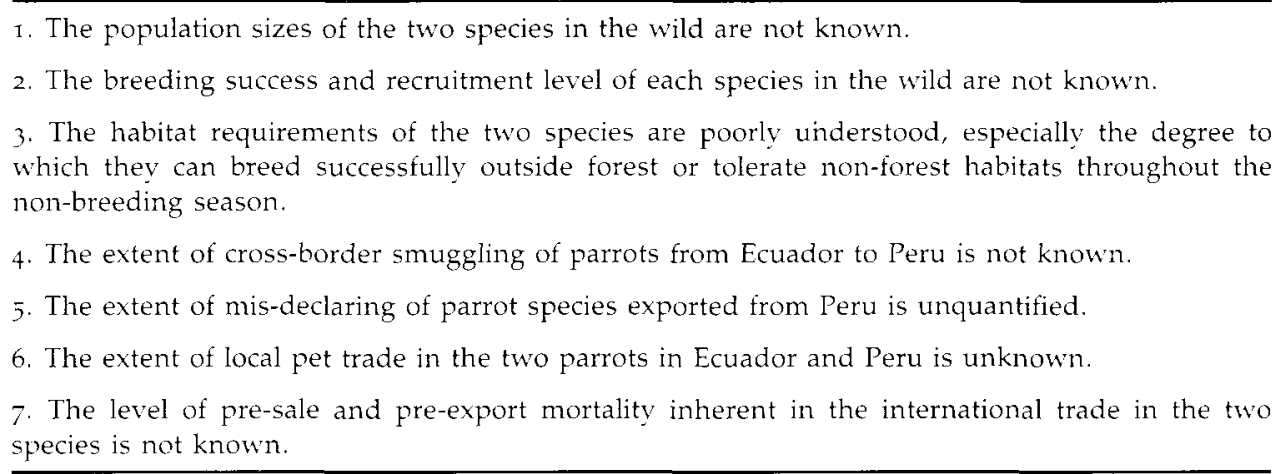

Inskipp and Corrigan (1992) concluded that international trade levels were likely to be having a serious effect on wild populations of this species. The CITES Animals Committee recommended that the CITES Management Authority of Peru establish a moratorium on exports pending a survey to determine the status of the populations in the country. This was adopted by the Peruvian government in March 1993.

Other threats This species is known to feed in agricultural land (sometimes around banana plantations) and as such may constitute a pest and be actively controlled by local farmers, but no data are available on this potential threat.

\section{Discussion}

The main aim of this paper is to determine whether enough information is available to classify $A$. erythrogenys and B. pyrrhopterus formally as threatened species. At least seven factors combine to make determination of the status of the two species difficult (Table 8). Therefore we believe that it is not possible to establish whether $A$. erythrogenys and B. pyrrhopterus are globally threatened at present.

Earlier in this paper we suggested that the numbers of $A$. erythrogenys and $B$. pyrrhopterus reported in trade may be exaggerated owing to deliberate misdeclaring of other parrot species as the legally traded Tumbesian parrots. However, we warn against using this as a criterion to remove the two species from the candidate threatened list, as domestic trade, pre-sale and pre-export mortality undoubtedly result in additional but unquantified numbers of parrots being removed from the wild. Thomsen and Bräutigam (1991) have shown that domestic sales in parrot species can form a substantial proportion of those actually in trade, citing the example of the Hyacinth Macaw Anodorlynchus hyacinthinus, whose domestic trade numbers have greatly exceeded those known in international trade in recent years. Pre-sale and pre-export mortality may also be high (Ramos and Iñigo 1985, Thomsen et al. 1992, T. Mulliken in litt. 1995), leading to a further underestimate of the numbers being affected in the wild. 
Table 9. Recommendations for the conservation of Aratinga erythrogenys and Brotogeris pyrrhopterus.

1. The government of Peru should implement an export ban on Aratinga erythrogenys pending research to establish that trade in the species from Peru is sustainable.

2. The population sizes, habitat requirements and ecology of A. erythrogenys and B, pyrrhopterus should be investigated by a field research programme.

3. The local collecting of the two species should be investigated further in order to determine trapping levels and assess the causes behind, and extent of, pre-sale mortality. Such data could help reduce pre-sale losses, thereby reducing the collecting pressure on the species.

4. Education programmes should be initiated with enforcement personnel in Peru, including parrot conservation issues and training in the identification of parrot species. This may help to reveal whether Peru's laws forbidding international trade in Amazonian parrots are being contravened.

5. Local education measures should be implemented in Ecuador and Peru informing both trappers and parrot owners of the relative rarity of, and potential threats to, both species. Trappers should be encouraged to see their endemic parrot species as a source of potential income only if trade is known to be sustainable. The parrots could be used as "flagship species" in more general conservation initiatives aimed at securing the future for the forests of the region.

6. The Ecuadorian authorities should be informed of the concern that their wild bird species may be being smuggled out of the country to Peru for domestic sale and export. They should be encouraged to implement stricter border controls and make border officials fully aware of the laws relating to the smuggling of Ecuador's wild bird species.

Such complicating factors indicate the difficulty in determining the conservation status of the two species. At present Ecuador and Peru, in common with many developing nations, lack the resources to assess their wild parrot populations and enforce CITES requirements effectively. Thomsen et al. (1992) cite these problems as the principal factors which prevent many countries from determining whether trade in their parrot populations is sustainable. There are many topics requiring urgent research effort (Table 8) and we suggest that only when detailed research on these has been carried out can a more precise assessment be made.

There are indications that local declines recorded in the populations of both species are caused by a combination of trapping and habitat loss, yet it is not known to what extent these declines are representative of more general and potentially far more serious population decreases. There is currently no convincing evidence that either species is under immediate threat of extinction in Ecuador and Peru.

However, we hope these conclusions will not be used by the Ecuadorian and Peruvian authorities to justify trade in these species, as further research must be carried out before trade is resumed. We commend the government of Peru for implementing a moratorium on trade in B. pyrrhopterus pending a review of its wild population as recommended by the CITES Animals Committee, and would suggest that a similar moratorium soon be imposed on $A$. erythrogenys. In Table 9 we suggest a number of interim recommendations, pending the results of the new research. These should, of course, go hand-in-hand with the wider conservation initiatives recently proposed for the Tumbesian region (Williams and Tobias 1994, Best and Kessler 1995). It is also important that the Peruvian and Ecuadorian governments seek and receive the full cooperation 
of their own national conservation organizations and NGOs, as well as the international conservation community, so that the areas of urgent research highlighted in Table 8 can be investigated in full. Only in this way can a sustainable and scientific basis for any future exploitation of the two species be guaranteed.

\section{Acknowledgements}

The authors would like to thank Teresa Mulliken of TRAFFIC International for important data relating to parrot trade, and for extensive improvements to the sections dealing with this issue. We thank C. S. Balchin, K. Berg, P. ChávezRiva, P. Coopmans, P. Donahue, P. Greenfield, M. Kessler, L. Kiff, M. Pearman, M. K. Poulsen, R. S. Ridgely, M. B. Robbins, T. S. Schulenberg, B. J. Weissgold and R. S. R. Williams for important field data. We are grateful to David Wege of BirdLife International for providing the distribution maps; Richard Thewlis kindly made the line drawings. T. Mulliken and R. S. Ridgely provided helpful comments on an earlier draft of this paper.

\section{References}

Allen, C. M. and Johnson, K. A. (1991) 1990 psittacine captive breeding survey. Washington, D.C.: TRAFFIC U.S.A.

Arndt, T. (1986) Südamerikanische Sittiche: Enzyklopädie der Papageien und Sittiche, 5. Bomlitz: Horst Müller.

Berg, K. S. (1994) New and interesting records of birds from a dry forest reserve in south-west Ecuador. Cotinga 2: 14-19.

Best, B. J., Broom, A. L., Checker, M. and Thewlis, R. M. (1992) An ornithological survey of El Oro and western Loja provinces, south-west Ecuador, January-March 1991. Pp.137-210 in B. J. Best, ed. The threatened forests of south-west Ecuador. Leeds, U.K.: Biosphere Publications.

Best, B. J. and Clarke, C. T., eds. (1991) The threatened birds of the Sozoranga region, southwest Ecuador. Cambridge, U.K.: International Council for Bird Preservation (Study Report 44).

Best, B. J. and Kessler, M. (1995) Biodiversity and conservation in Tumbesian Ecuador and Peru. Cambridge, U.K.: BirdLife International.

Bloch, H., Poulsen, M. K., Rahbek, C. and Rasmussen, J. F. (1991) A survey of the montane forest avifauna of the Loja province, southern Ecuador. Cambridge, U.K.: International Council for Bird Preservation (Study Report 49).

Brosset, A. (1964) Les oiseaux de Pacaritambo (Ouest de l'Ecuador). Oisean et R.F.O. 34: $1-24,112-135$.

Chapman, F. M. (1926) The distribution of bird-life in Ecuador. Bull. Amer. Mus. Nat. Hist. 55 .

Chávez-Riva, P. (1991) Biología reproductiva y conservación de la Cotorra de Cabeza Roja Aratinga erythrogenys. Paper given at the IV Neotropical Ornithological Congress, Quito, November 1991.

Collar, N. J. and Andrew, P. (1988) Birds to watch: the ICBP world check-list of threatened birds. Cambridge, U.K.: International Council for Bird Preservation (Techn. Publ. 8).

Collar, N. J. and Juniper, A. T. (1992) Dimensions and causes of the parrot conservation crisis. Pp.1-24 in S. R. Beissinger and N. F. R. Snyder, eds. New World parrots in crisis: solutions from conservation biology. Washington, D.C.: Smithsonian Institution Press. 
Collar, N. J., Gonzaga, L. P., Krabbe, N., Madroño Nieto, A., Naranjo, L. G., Parker, T. A. and Wege, D. C. (1992) Threatened birds of the Americas: the ICBP/IUCN Red Data Book. Cambridge, U.K.: International Council for Bird Preservation.

Collar, N. J., Crosby, M. J. and Stattersfield, A. J. (1994) Birds to watch 2: the world list of threatened birds. Cambridge, U.K.: BirdLife International (BirdLife Conservation Series no. 4).

Cracraft, J. (1985) Historical biogeography and patterns of differentiation within the South American avifauna: areas of endemism. Pp.49-84 in P. A. Buckley, M. S. Foster, E. S. Morton, R. S. Ridgely and F. G. Buckley, eds. Neotropical ornithology. Washington, D.C.: American Ornithologists' Union (Orn. Monogr. 36).

Desenne, P. and Strahl, S. D. (1991) Trade and the conservation status of the family Psittacidae in Venezuela. Bird Conserv. Internatn. 1: 153-169.

Dodson, C. H. and Gentry, A. H. (1991) Biological extinction in western Ecuador. Ann. Missouri Bot. Gard. 78: 273-295.

Fuller, K. S., Swift, B., Jorgenson, A. and Bräutigam, A. (1987) Latin American wildlife trade laws. Second (revised) edition. Washington, D.C.: World Wildlife Fund-U.S.

Harris, R. (1985) Grey-cheeked Parakeets and other Brotogeris. Neptune City, New Jersey: TFH Publications.

Inskipp, T. P. and Corrigan, H. (1992) Review of significant trade in animal species included in CITES Appendix II: detailed reviews of 24 priority species. Cambridge, U.K.: World Conservation Monitoring Centre/IUCN Trade Specialist Group.

Mace, G. and Stuart, S. (1994) Draft IUCN Red List categories. Species 21-22: 13-24.

Marchant, S. (1958) The birds of the Santa Elena Peninsula, S.W. Ecuador. Ibis 100: $349-$ 387.

O'Neill, J. P. (1981) Comments on the status of the parrots occurring in Peru. Pp.419-424 in R. F. Pasquier, ed. Conservation of New World parrots. Washington, D.C.: Smithsonian Institution Press for the International Council for Bird Preservation (Techn. Publ. 1).

Parker, T. A., Schulenberg, T. S., Kessler, M. and Wust, W. H. (1995) Natural history and conservation of some endemic birds from north-west Peru. Bird Conserv. Internatn. 5: 201-231.

Platt, D. (1991) Tráfico de Brotogeris pyrrhoptertus en sur oeste Ecuatoriano. Paper given at the IV Neotropical Ornithological Congress, Quito, November 1991.

Plowden, C. (1987) The bird trade in Peru: a report on the Peruvian bird trade with emphasis on exports to the United States. Washington, D.C.: The Humane Society of the United States.

Ramos, O. M. and Iñigo, E. (1985) Comercialización de Psitácidos en México. In Proceedings of the 1st International Symposium on Tropical Fauna, 2. Mexico.

Ridgely, R. S. (1981) The current distribution and status of mainland Neotropical parrots. Pp. 233-384 in R. F. Pasquier, ed. Conservation of New World parrots. Washington, D.C.: Smithsonian Institution Press for the International Council for Bird Preservation (Techn. Publ. 1).

Ridgely, R. S. and Tudor, G. (1989) The birds of South America, 1. Oxford, U.K.: Oxford University Press.

Silva, T. (1993) A monograph of macaws and conures. Pickering, Canada: Silvio Mattacchione.

Stattersfield, A. J., Crosby, M. J., Long, A. J. and Wege, D. C. (in prep) Global directory of endemic bird areas. Cambridge, U.K.: BirdLife International (BirdLife Conservation Series).

Thomsen, J. B and Bräutigam, A. (1991) Sustainable use of Neotropical parrots. Pp.359379 in J. G. Robinson and K. H. Redford, eds. Neotropical wildlife use and conservation. Chicago: University of Chicago Press.

Thomsen, J. B. and Mulliken, T. A. (1992) Trade in Neotropical Psittacines and its conservation implications. Pp.221-237 in S. R. Beissinger and N. F. R. Snyder, eds. New 
World parrots in crisis: solutions from conservation biology. Washington, D.C.: Smithsonian Institution Press.

Thomsen, J. B., Edwards, S. and Mulliken, T. (1992) Perceptions, conservation and management of wild birds in trade. Cambridge, U.K.: TRAFFIC International.

Wiedenfeld, D. A., Schulenberg, T. S. and Robbins, M. B. (1985) Birds of a tropical deciduous forest in extreme northwestern Peru. Pp.305-315 in P. A. Buckley, M. S. Foster, E. S. Morton, R. S. Ridgely and F. G. Buckley, eds. Neotropical ornithology. Washington, D.C.: American Ornithologists' Union (Orn. Monogr. 36).

Williams, R. S. R. and Tobias, J. A. (1994) The conservation of southern Ecuador's threatened avifauna: final report of the Amaluza 1990-1991 projects. Cambridge, U.K.: BirdLife International (Study Report 60).

BRINLEY J. BEST and AMANDA L. BEST

9 Throstle Nest Close, Otley, West Yorkshire, LS21 2RR, U.K.

NIELS KRABBE

Casilla 17-21-791, Quito, Ecuador

CHRISTOPHER T. CLARKE

University of East Anglia, Norwich, Norfolk, NR4 7TJ, U.K. 